Elżbieta Paczkowska-Łagowska

Uniwersytet Jagielloński, Kraków

e-mail: paczkowskalagowska@gmail.com

\title{
Struktura osobowości a proces cywilizacji. Nota na temat historyczności człowieka w rozważaniach Norberta Eliasa
}

DOI: http://dx.doi.org/10.12775/RF.2017.022

Obraz człowieka w dziele Norberta Eliasa O procesie cywilizacji. Analizy socjo- $i$ psychogenetyczne ${ }^{1}$ zakrojony jest na miarę długofalowych procesów, jakim podlega on w trakcie własnego ucywilizowania (do „długofalowej" perspektywy jego socjologii nawiązuje tytuł książki Marty Bucholc) $)^{2}$. W centrum procesu cywilizacji w „wielogłosowym” dziele, łączącym wątki socjologiczne, psychologiczne, historyczne i kulturoznawcze, stoi człowiek w swoim zmiennym dziejowo upostaciowaniu. Studia nad procesem cywilizacji, zamierzone $\mathrm{w}$ ujęciu autora wprawdzie jako „psychologia historyczna”, mają jednak swój coraz bardziej ujawniający się aspekt antropologiczny, dzięki któremu mogą być odczytane jako cenne świadectwo i przedmiot dyskusji dla filozoficznego, a jednocześnie interdyscyplinarnego zainteresowania człowiekiem, jakie właściwe jest naszym czasom. U podstaw niniejszej noty tkwi zamiar wydobycia z wielowątkowego dzieła Eliasa myśli przemawiających na

1 N. Elias, O procesie cywilizacji. Analizy socjo- i psychogenetyczne, przeł. T. Zabłudowski i K. Markiewicz, Wydawnictwo WAB, Warszawa 2011. Dzieło poprzedzone przedmową Marty Bucholc U źródeł socjologii procesów społecznych. Wstęp do pierwszego petnego polskiego wydania "O procesie cywilizacji" Norberta Eliasa, ibidem. Przedmowa zawiera wiadomości biograficzne oraz cenny, wszechstronnie i z wysokim znawstwem nakreślony rys sylwetki intelektualnej Eliasa. Przypomnijmy tu, że oryginał dzieła ukazał się w roku 1939.

2 M. Bucholc, Samotność długodystansowca. Na obrzeżach socjologii Norberta Eliasa, Wydawnictwo Naukowe PWN, Warszawa 2013. 
rzecz historyczności człowieka, aspektu podnoszonego przez filozofię współczesną przynajmniej od czasów Wilhelma Diltheya. W dalszej części zadamy pytanie, w jakim sensie ludzkiemu istnieniu, zarówno w jego wymiarze indywidualnym, jak i rodzajowym, można na podstawie rozważań Eliasa przypisać charakter historyczny. Następnie zaś spróbujemy odpowiedzieć na pytanie, jakie znaczenie mogą mieć rozpoznania Eliasa dla kształtującej się stopniowo antropologii historycznej. Aby dostarczyć materiału do odpowiedzi na te pytania, rozpocznijmy od antypodów jego koncepcji.

Negatywnym biegunem odniesień, przeciwieństwem człowieka całościowego postulowanego przez Eliasa, a przede wszystkim długofalowo-procesualnego, jest homo clausus. Homo philosophicus, podobnie jak sociologicus i historicus, to jego podporządkowane uszczegółowienia/ /ucieleśnienia. Homo clausus to niewątpliwie konstrukt teoretyczny, rodzaj Vaihingerowskiej „fikcji”, skrót teoretyczny, nie mający odpowiednika w życiowej rzeczywistości, a służący jedynie za poręczny chwyt, z pomocą którego uprawiano naukę o człowieku. Różnym teoriom, w tym filozoficznym, które operowały pojęciem takiego człowieka bynajmniej nie przeszkadzał fakt jego rzeczywistego nieistnienia.

Scharakteryzujmy aspekty tego sztucznego tworu, nazywanego przez Eliasa homo clausus. Jest to osobowość zamknięta, wewnętrznie suwerenna, czyli obywająca się bez innych ludzi i obojętna na rezultaty międzyosobowej wymiany we wzajemnym oddziaływaniu. Zasób wewnętrzny tej osobowości dany jest niejako z góry i nie podlega procesowi przemian w indywidualnym rozwoju. Homo clausus przychodzi na świat jako jednostka dojrzała i suwerenna, która nigdy nie była dzieckiem. Przedstawia on abstrakcyjny podmiot poznania, a zatem konstrukcję zredukowaną do czystej władzy poznawczej. Taki podmiot stał się już wcześniej, mianowicie pod koniec XIX wieku, obiektem krytyki Wilhelma Diltheya, z którym Eliasa łączy zasadniczo historyczne widzenie człowieka. Koncepcja homo clausus traktuje człowieka jako osobę dojrzała, która dysponuje określonym zasobem wiedzy, bez uwidoczniania samego procesu zdobywania jej w przechodzeniu stadiów rozwoju indywidualnego. „Proces - pojedynczy człowiek jako proces dorastania oraz ogół ludzi jako proces rozwoju ludzkości - w wymiarze teoretycznym podlega redukcji do aspektu stanu" ${ }^{\prime 3}$. Koncepcja homo clausus nie uwzględnia procesualności ludzkiego życia, wymiany z innymi ludźmi, w szczególności procesu uczenia się. Homo clausus ma zatem naturę monadyczna, pojawia się z góry jako człowiek dojrzały i żyje $w$ taki sposób, jak gdyby świat zewnętrzny dla niego nie istniał, a w jego wnętrzu przebiegał "niewidoczny mur". Odmianą homo clausus jest homo philosophicus (jak również oeconomicus, psychologicus, sociologicus). Występują

${ }^{3}$ N. Elias, O procesie cywilizacji..., op. cit., s. 51. 
oni w klasyce odnośnej literatury: „Wizerunek pojedynczego człowieka w koncepcjach Kartezjusza, Webera i Parsonsa oraz wielu innych socjologów ulepiony został z tej samej gliny"4.

Przypomnijmy, że takiego człowieka zubożonego i zredukowanego do postaci zwykłego „podmiotu poznania" uczynił obiektem krytyki już w roku 1883 Wilhelm Dilthey, proponując w zamian człowieka w pełni jego rzeczywistych sił, odpowiadających wielości punktów widzenia różnych nauk humanistycznych. Przytoczmy jego słowa dla zaznaczenia wspólnoty z Eliasem, która następnie zaprowadzi nas dalej:

W żyłach poznającego podmiotu, jaki konstruowali Locke, Hume i Kant, nie płynie rzeczywista krew, lecz rozcieńczony sok rozumu jako samej czynności myślenia. Mnie natomiast historyczne, jak też psychologiczne zajmowanie się człowiekiem doprowadziło do tego, aby tę chcąca, czująca, przedstawiającą sobie istotę położyć u podstaw objaśniania poznania i jego pojęć, takich jak świat zewnętrzny, czas, substancja, przyczyna [...] Metoda niniejszej próby jest zatem następująca: każdą część składową współczesnego abstrakcyjnego, naukowego myślenia odnoszę do całości natury ludzkiej w sposób, jaki ukazuje ją doświadczenie, badanie języka i dziejów, i poszukuję jej spoistości. I w ten sposób okazuje się: najważniejsze części składowe naszego obrazu i naszego poznania rzeczywistości, takie jak osobowa jedność życia, świat zewnętrzny, jednostki poza nami, ich życie w czasie i ich oddziaływanie wzajemne, wszystkie one mogą zostać objaśnione z całościowej natury ludzkiej, której rzeczywisty proces życiowy ma swoje różne strony $\mathrm{w}$ chceniu, czuciu i przedstawianiu. To nie przyjęcie jakiegoś sztywnego a priori naszej władzy poznawczej, lecz jedynie dzieje rozwoju, jakie wychodzą od totalności naszej istoty, mogą odpowiedzieć na pytania, jakie kierujemy wobec filozofii ${ }^{5}$.

Tak więc kluczowymi pojęciami w Diltheyowskiej koncepcji człowieka są całość/totalność i proces rozwoju. Ich obecność pozwala nam na zestawienie intencji Diltheya z ujęciem Eliasa, zwłaszcza w aspekcie negatywnym. Dodajmy, że Dilthey często powtarzał, że tego, kim człowiek jest, dowiaduje się on dopiero ze swojej historii, że człowiek nie ma natury, lecz historię. Norbert Elias zdaje się podążać śladem tych myśli, zmierzać w kierunku wskazanym przez drogowskaz „historyczności człowieka", chociaż nie powołuje się na Diltheya. Tym bardziej oryginalne, a nawet wiarygodne w rezultatach okazują się jego własne odkrycia w obszarze "historyczności"; świadczą bowiem o poszukiwaniach podjętych z impulsu niezależnego od wpływów Diltheyowskich

4 Ibidem, s. 53.

5 W. Dilthey, Einleitung in die Geisteswissenschaften. Versuch einer Grundlegung für das Studium der Gesellschaft und der Geschichte, in: idem, Gesammelte Schriften, I. Band, B.G. Teubner Verlagsgesellschaft Stuttgart, Vandenhoeck \& Ruprecht in Göttingen, wyd. 7 niezmienione, s. XVIII. 
i tkwiącego w jego własnej, na wskroś interdyscyplinarnej orientacji humanistycznej.

Pod pewnym szczególnie nas tu interesującym względem badań nad „historycznością człowieka" ${ }^{6}$ można przypisać Eliasowskim analizom wartość poznawczą porównywalną z klasycznymi już ustaleniami Diltheya. Dilthey wskazał niewątpliwie kierunek, w jakim należy pójść, a zarazem nakreślił obraz człowieka, jaki należy porzucić - mianowicie powstały na drodze ustalania jego rzekomo ponadczasowej istoty. Jego wezwania i apele domagają się jednak wypełnienia konkretną treścią. I oto pojawia się Norbert Elias, który Diltheyowską koncepcję człowieka historycznego wypełnia bogactwem treści, przedstawia w sposób intuicyjnie zrozumiały i poglądowy, wskazując, że różne obecne w tradycji filozoficznej obrazy człowieka stanowią historycznie dostępne we właściwych sobie czasach jego ujęcia, których nie należy z osobna absolutyzować, generalizować, stawiać poza czasem i pod szyldem „,antropologii filozoficznej", wznosić na poziom stałej i niezmiennej natury ludzkiej. Co naturalnie jeszcze nie znaczy, że nie istnieje "specyfika bytu ludzkiego" - jak wyraża się Elias. Socjologiczny punkt widzenia każe mu sądzić, że

tym, co zmienia się w ruchu, który nazywamy historią są [...] stosunki wzajemne między ludźmi i sposób, w jaki w przebiegu dziejów modelują one jednostkę. Lecz właśnie z chwila, gdy się odsłania przed nami ta fundamentalna historyczność ludzi, odsłania się również prawidłowość, specyfika bytu ludzkiego, która pozostaje niezmienna ${ }^{7}$.

To nie natura ludzka się zmienia, lecz zmieniają się formy ludzkiego życia, w szczególności struktura osobowości/świadomości/emocjonalności. To, co naturalne, jawi się zawsze w określonym kształcie, szczególnym „wymodelowaniu” historycznym. Nie można więc natury ludzkiej poszukiwać poza historią. Rozważania Norberta Eliasa nad procesem cywilizacji pozwalają nam na odkrycie i sformułowanie znaczeń, w jakich można mówić o „historyczności” człowieka, nie rezygnując zarazem z przekonania, że istnieje "specyfika bytu ludzkiego".

Również Dilthey mówił o „tożsamości natury ludzkiej”, zaznaczając zarazem, że należy jej poszukiwać w historii, że o człowieku należy myśleć w kategoriach „historii” mimo istnienia naturalnych wyznaczników ludzkiego bycia. Uznał, że intelekt, wola i uczucie należą do ludzkiej natury, jednak ich proporcje - struktura świadomości/osobowości, jak powiedzielibyśmy - są u różnych typów ludzi rozmaite. Ludzie różni-

${ }^{6}$ Autorka podjęła je w książce: E. Paczkowska-Łagowska, O historyczności człowieka. Studia filozoficzne, Słowo/obraz terytoria, Gdańsk 2012.

7 N. Elias, O procesie cywilizacji..., s. 539. 
liby się zatem od siebie strukturą życia psychicznego i odpowiednią do niej odmiennością widzenia świata poprzez jej pryzmat. I tak istnieją struktury osobowości opanowane przeważająco przez intelekt, wolę, względnie uczucie. Jest to podział, który doprowadził Diltheya do typologii trzech światopoglądów, właściwych odpowiednio różnym typom osobowości ${ }^{8}$. Skrótowo rzecz ujmując, intelektualizm prowadzi do naturalizmu, dominacja woli do idealizmu wolności, panowanie uczucia do idealizmu obiektywnego. Do scalenia tych trzech różnych aspektów ludzkiego życia, wyrażających się w typach światopoglądów, dochodzi się dopiero $\mathrm{w}$ dziejach filozofii: prawda filozoficzna nie pojawia się w czystej postaci, lecz dana jest jedynie w rozmaicie załamanych promieniach typów światopoglądów ${ }^{9}$. Rany zadane człowiekowi całościowemu przez świadomość historyczna, mianowicie rozdarcie jego osobowości na intelekt, wolę i uczucie - zostają przez tę samą świadomość historyczną w jej funkcji „sscalającej” uleczone. Człowiek uzyskuje utraconą jedność swojego bytu dopiero w oglądzie dziejów, gdy - uprawiając historię filozofii/historię idei - dochodzi w późnym okresie historycznym do oglądu swoich możliwości w świadomości historycznej. Łączne wystąpienie tych trzech ukierunkowań światopoglądowych nie jest możliwe; reprezentują one bowiem stanowiska nie do połączenia. Jednak ich ogląd jako trzech różnych możliwości interpretowania świata i życia, w tym człowieka, dostępny jest dla świadomości historycznej.

Widzenie człowieka i jego spraw w perspektywie historycznej przy jednoczesnym uznaniu "tożsamości natury ludzkiej” przez Diltheya $\mathrm{i}$ „,niezmiennej specyfiki bytu ludzkiego" przez Eliasa pozwala nam na sparalelizowanie ich stanowisk i w rezultacie może również na bliższe określenie, na czym polega „historyczność” człowieka.

Norbert Elias jest uznanym i w miarę odkrywania coraz bardziej cenionym klasykiem socjologii. Ze względu na interdyscyplinarność swoich badań nad procesem cywilizacji, studiów uwzględniających perspektywę psychologiczną i historyczną (nazywa je psychologią historyczna, a nie antropologią kulturową czy historyczną), wykracza poza wąsko i po akademicku rozumianą specjalność socjologiczną w kierunku interdyscyplinarnych badań nad człowiekiem. Jego wielowątkowe dzieło O procesie cywilizacji - oparty na bogatej erudycji humanistycznej obraz cywilizacyjnego postępu człowieka poprzez dzieje - daje do myślenia

8 Na ten temat por. W. Dilthey, Typy światopoglądów $i$ ich rozwinięcie w systemach metafizycznych, w: W. Dilthey, O istocie filozofii $i$ inne pisma, przeł. E. Paczkowska-Łagowska, PWN, Warszawa 1987.

${ }_{9} \mathrm{~W}$ sposób syntetyczny Dilthey przedstawia ten temat $\mathrm{W}$ przemówieniu z okazji swoich 70. urodzin (1903), zatytułowanym „Sen”. Zob. w książce Zbigniewa Kuderowicza Dilthey, Wiedza Powszechna, Warszawa 1967, wybór pism Diltheya w przekładzie Krystyny Krzemieniowej. 
filozofii, antropologii filozoficznej, filozofii dziejów. Przede wszystkim pozwala na nowo postawić przewijające się w filozofii współczesnej pytanie o „historyczność" człowieka, uzmysłowić, na czym miałaby ona w szczegółach polegać, jeśli spojrzeć na człowieka z perspektywy uzupełniających się nawzajem pozycji socjologa, psychologa i historyka, ze szczególnym uwzględnieniem warsztatu badacza obyczajów, jak również teoretyka kształtowania się monopolistycznych struktur państwowości.

Optykę historyczności przykłada Elias zarówno do człowieka indywidualnego, jak i do całych społeczności, a w końcu do postępującej poprzez dzieje ludzkości. Przedstawia nam zatem nie tylko obraz jednostki wobec innych ludzi w społeczeństwie, ale także ludzkość rozwijającą się $\mathrm{w}$ dziejach, zatem punkt widzenia zarazem antropologii filozoficznej i filozofii dziejów, w sumie rezultat wielkiej syntezy humanistycznej. W niniejszym artykule o charakterze wstępnej noty do dalszych badań ukierunkowanych antropologiczno-filozoficznie nie można oczywiście pretendować do objęcia wszystkich tych aspektów; taka ambicja byłaby możliwa do urzeczywistnienia dopiero $\mathrm{w}$ rozmiarach proporcjonalnie odpowiadających sześciuset stronicowemu opracowaniu samego Elia$\mathrm{sa}^{10}$. Ograniczamy się zatem do odpowiedzi na pytanie, na czym zdaniem Eliasa polega historyczność człowieka i w jaki sposób jego badania nad cywilizacją przyczyniając się do rozwoju antropologii historycznej, mogą stanowić istotny wkład $\mathrm{w}$ rozważanie filozoficznie doniosłego problemu wyrażonego w ogólnym haśle „natura ludzka a historia”.

Badaczom filozofii współczesnej w Polsce, zwłaszcza antropologom filozoficznym, uwagę na doniosłość problematyki podnoszonej przez Norberta Eliasa zwrócił Gernot Böhme w książce Antropologia filozoficzna. Ujęcie pragmatyczne ${ }^{11}$. W rozdziale zatytułowanym Antropologia historyczna podaje on antycypujące przykłady dziedziny naukowej, która nie istnieje wprawdzie jako ustabilizowana dyscyplina, jednak jej prolegomena dają się współcześnie wyśledzić; autor dostrzega je między innymi w dziele Eliasa o procesie cywilizacji.

Jak wskazywaliśmy na wstępie, negatywnym przedmiotem odniesień Eliasa jest „homo clausus”. Okazuje się on odpowiadać określonej koncepcji człowieka, która sama jest tworem historycznym; powstała mianowicie $\mathrm{w}$ okresie nowożytnym i stała się prototypem podmiotu

${ }^{10} \mathrm{~W}$ języku polskim z pozycji monograficznych obok wymienionej wyżej książki Marty Bucholc, zachęcającej swoim doskonałym stylem do dalszej lektury pozostałych pism Eliasa, poza dziełem o cywilizacji znajdujemy interesującą książkę Katarzyny Suwady: idem, Miłość erotyczna w procesie cywilizacji. Próba interpretacji koncepcji Norberta Eliasa, Nomos, Kraków 2013. Książka zawiera również obszerną biografię intelektualną Eliasa.

11 G. Böhme, Antropologia filozoficzna, przeł. P. Domański, Wydawnictwo IFiS PAN, Warszawa 1998. 
poznania w epistemologii kartezjańskiej. Jak już wskazywaliśmy, jest to podmiot $\mathrm{w}$ tym sensie suwerenny, że wyizolowany ze społeczeństwa. Człowiek ten zakwestionował geocentryczny obraz świata, w rezultacie czego wycofał się ze swojej pozycji centralnej, „usunął z centrum”"12 i stał się suwerennym centrum sam dla siebie. $W$ ten sposób człowiek nowożytny poczuł się w swojej autonomiczności jako jednostka całkowicie niezależna. Właściwie nie powinno się w tym kontekście mówić o jednostce, wówczas bowiem stawiamy ją wobec społeczeństwa, lecz o „podmiocie", umieszczając go tym samym wobec "przedmiotu” w kontekście dyskursu epistemologicznego. Sposobu, w jaki doświadczali siebie ludzie nowożytni nie można jednak, zdaniem Eliasa, uogólniać w postać odpowiedzi na pytanie, czym jest człowiek w ogóle. Człowieka nowożytnego charakteryzuje dystans do siebie, powściągliwość afektów i zjawiska te mają związek z odrzuceniem geocentrycznej koncepcji kosmosu. Zgodnie z tą ostatnią człowiek stał w centrum Ziemi, wokół której krążyło Słońce i za taki porządek rzeczy odpowiadał Bóg, który go ze względu na człowieka i wraz z nim, stworzył. Odrzucenie wizji geocentrycznej pociągnęło za sobą usunięcie się człowieka z zajmowanego przez niego położenia centralnego; tym samym znalazł się na peryferiach, stał się "ekscentryczny". To wycofanie się z centrum pozwoliło mu spojrzeć na siebie jako na jednostkę autonomiczna, skupioną na samej sobie, nie zorientowaną na żaden wyższy ład - i tak powstał nowożytny homo clausus. Naturalnie nie jest to człowiek całościowy w pełni jego sił, nie jest to również jednostka podlegająca oddziaływaniu innych ludzi i w trakcie tego odnoszenia się i jego zmiennych form sama ulegająca zmienności.

Jednostkę ludzką w trakcie historii "modelują" stosunki międzyludzkie, formy życia, czy - jak je nazywa Elias - figuracje.

Pytanie, dlaczego zmienia się sposób zachowania i struktura emocjonalna ludzi, jest w gruncie rzeczy pytaniem o to, dlaczego zmieniają się formy ludzkiego życia. Społeczeństwo średniowieczne wykształciło określone formy życia i życie jednostki kształtowało się w ramach tych form, czy to jako życie rycerza, czy to rzemieślnika cechowego lub chłopa pańszczyźnianego. Społeczeństwa faz późniejszych otwierały przed jednostką inne możliwości, wykształciły inne formy życia, do których musiała się ona przystosować $[\ldots]$ Jest to $\mathrm{w}$ gruncie rzeczy to samo pytanie, co pytanie o przyczyny, jakie sprawiaja, że zmienia się struktura i funkcjonowanie popędów, model życia emocjonalnego i wszystko, co się z tym wiąż $\mathrm{e}^{13}$.

W procesie cywilizacji istnieje zatem korelacja/zależność między rodzajem stosunków międzyludzkich, stylami życia przez nie ukształto-

12 N. Elias, O procesie cywilizacji..., s. 53.

13 Ibidem, s. 272. 
wanymi a sposobem/modelem funkcjonowania popędów/życiem emocjonalnym. Właśnie tych aspektów ludzkiego życia w ich plastyczności brakuje Eliasowi w koncepcji homo clausus. (Przypomnijmy, że ich obecności domagał się również Dilthey, co wcześniej zostało udokumentowane). Ograniczenia tego typu abstrakcyjnej koncepcji pragnie Elias znieść otwarciem człowieka na stosunki międzyludzkie i uwzględnieniem w osobowości ludzkiej popędów oraz emocji, które w procesie cywilizacji podlegają "modelowaniu”.

Zasługą Eliasa dotyczącą koncepcji homo clausus jest już samo wykazanie, że ma on historyczne korzenie i że u podstaw tej fikcji tkwi odejście od geocentrycznego oglądu kosmosu. Ten historycznie ukształtowany i niesłusznie "wyabsolutniony", umieszczony poza historią obraz człowieka jako „osobowości zamkniętej” przeciwstawia Elias „osobowości otwartej” - „cechującej się wprawdzie mniejszym lub większym stopniem autonomii, nigdy jednak absolutnej i całkowitej, istoty ukierunkowanej przez całe życie na innych, na nich zdanej i od nich zależnej"14. Człowiek występuje dla Eliasa w liczbie mnogiej - jako ludzie, czyli zawsze w siatce wzajemnych powiązań i zależności, tak zwanych przez niego figuracji. Figuracja to „tworzona przez jednostki sieć współzależności"15. Rezygnacja z koncepcji człowieka zamkniętego pozwala Eliasowi mówić o procesie cywilizacji jako zmianie struktur indywidualnych pod wpływem zmian figuracji.

Przystępując do odtworzenia w największym skrócie Eliasowskiego obrazu procesu cywilizacyjnego, przypomnijmy nasze pytanie przewodnie: Jaki może być rezultat, jaka owocność filozoficzna badań nad człowiekiem prowadzonych $\mathrm{w}$ aspekcie rozwoju jego cywilizacji? Znamy rezultat psychologiczny; polega on na ukazaniu, że wraz z rozwojem cywilizacji zmienia się struktura osobowości, świadomości. Jakie znaczenie może mieć to rozpoznanie dla antropologii filozoficznej? Otóż jeśli antropologia filozoficzna pragnie rozpoznać całość rzeczywistości człowieka, to nie może przejść obojętnie wobec tych aspektów tej rzeczywistości, które ujawnia interdyscyplinarne badanie humanistyczne, łączące socjologię z psychologią i historią. Elias bowiem toruje "drogę do zrozumienia procesu cywilizacji $\mathrm{w}$ wymiarze psychicznym"16 i posługuje się przy tym metodą socjologii historycznej. Antropologia filozoficzna nie obejmowała dotąd zjawisk należących do psychologii społecznej, "psychologii historycznej” - i w rezultacie nie była wystarczająco uwrażliwiona na zjawisko „historyczności” człowieka. Warto jednak, aby się szerzej na nie otworzyła, skoro tak spektakularnie udało się tego dokonać Eliasowi w jego psychologii historycznej. Filozofowie już zwra-

14 Ibidem, s. 63.

15 Ibidem, s. 64.

16 Ibidem, s. 68. 
cają uwagę na te badania, co odpowiada potrzebie interdyscyplinarności badań nad człowiekiem. Jak już wspomnieliśmy, literaturę socjologiczną i psychologiczno-społeczną wciągnął do badań antropologicznych Gernot Böhme i u niego znajdujemy również trop prowadzący do dzieła Eliasa. Obecnie, gdy ukazał się pełen przekład na język polski jego dzieła głównego, warto jest uwzględnić jego przekaz myślowy w badaniach antropologicznych i przynajmniej zadać sobie pytanie o przydatność i walor poznawczy studiów „psychologii historycznej” dla antropologii filozoficznej ${ }^{17}$.

Że człowiek posiada popędy, jest ogólnym przeświadczeniem psychologii, socjologii i w ogóle nauk humanistycznych, przede wszystkim zaś antropologii filozoficznej, zarówno w aspekcie fizjologicznym, jak pragmatycznym, jak ujął by to Kant. Człowiek jest bowiem nie tylko jako natura wyposażony w popędy, ale jako historia jest tym, w jaki sposób zdoła je okiełznać, wymodelować, wysublimować, przetworzyć w dzieło. Nie wiadomo wprawdzie, ile człowiek tych popędów posiada; Helmuth Plessner gdzieś żartuje, że rozrzutni autorzy dochodzą do pięćdziesięciu, inni, oszczędniejsi, pozostają przy trzech zasadniczych: popędzie do odżywiania, popędzie seksualnym oraz popędzie do mocy i znaczenia. Te popędy można traktować jako względnie (w zależności od uznania danego autora) „stałe antropologiczne”. Jednak sposób funkcjonowania tych popędów, ich struktura, model życia emocjonalnego zmienia się w historii. Na przykładach z zakresu form zachowania się przy stole, spożywania posiłków, odnoszenia się do drugiej płci, zachowania w sypialni i innych zachowań opisuje Elias sposób funkcjonowania tych popędów, zmienny w procesie historycznym. Owa zmienność w funkcjonowaniu popędów, a ściślej - stopniowe ich opanowywanie, jest drogą do cywilizacji. Otóż w drodze do cywilizacji, która jest procesem historycznym, następuje ucywilizowanie popędów. W procesie cywilizacyjnym dokonuje się zatem swoiste współoddziaływanie czynnika naturalnego (owej „stałej antropologicznej”) i historycznego. Życie popędowe, zdawałoby się spontaniczne, żywiołowe i na wskroś naturalne, podlega według Eliasa społecznemu modelowaniu, w rezultacie czego powstają „formy życia”. Nie sposób zbadać przemian w ludzkiej świadomości i strukturze popędów, nie uwzględniając procesów historycznych. W rozważaniach Eliasa tymi procesami decydującymi o zmianach struktury osobowości/świadomości i struktury popędów są procesy kształtowania się państwa i rozwoju absolutyzmu.

Koncepcja homo clausus nie pozwalała zrozumieć procesu cywilizacji, $\mathrm{w}$ trakcie którego w długim trwaniu historycznym i powoli dochodzi do

17 Pierwsze niepełne wydanie dzieła N. Eliasa pt. Przemiany obyczajów w cywilizacji Zachodu w przekładzie Tadeusza Zabłudowskiego ukazało się w PWN, Warszawa w roku 1980. 
przeobrażeń osobowości, do zmiany struktury świadomości jednostki. Ta zmiana odbywa się dzięki postępującej w procesie cywilizacji coraz to większej kontroli afektów. Tego rodzaju kontrolę może sprawować absolutystyczna władza centralna - stąd jej rola w procesie cywilizacji, do czego jeszcze powrócimy.

Zasadniczą myślą Eliasa, dzięki której przyciąga on zainteresowanie antropologii filozoficznej, jest stwierdzenie, że struktura życia emocjonalnego ludzi innych epok była odmienna od naszej. Dlatego też filozof może z tego rozpoznania wyciągnąć wniosek, że żadnego z typów emocjonalności czy osobowości nie należy izolować z procesu historycznego $\mathrm{i}$ „,wyabsolutniać” w postać istotowo pojętej natury ludzkiej. Historyczność wycisnęła swoje piętno przede wszystkim na życiu emocjonalnym człowieka. Tak fundamentalne i po wielekroć filozoficznie badane uczucia wstydu/zawstydzenia i odczuwania przykrości dane są człowiekowi wprawdzie od natury, jednak w konkretnej postaci występują jako „wymodelowane" - jak wyraża się Elias - odpowiednio do standardu przymusu, jaki do jednostki przychodzi z zewnątrz ${ }^{18}$. Rozwój cywilizacji oznacza potęgowanie się wewnętrznego nakazu samokontroli, wzrost „uwrażliwienia” polegający na przesuwaniu się progu uczuć wstydu i zakłopotania, w rezultacie czego kształtuje się stopniowo jednostka obliczalna i przewidywalna, powściągliwa, wrażliwa na innych. Civilitas oznacza wszak obycie, grzeczność. Procesy tego uwrażliwienia śledzi Elias na podstawie podręczników dobrych manier, przekazanych w pismach między innymi Erazma z Rotterdamu, Balthasara Castiglione, Giovanniego della Casy. Materiałem jego badań są ich relacje na temat zarówno rzeczywistych, jak i pożądanych zachowań ludzkich związanych z ciałem, głównie dotyczące zachowania się przy stole i w sypialni. Niezależnie od swojej wartości dla teorii ukazującej proces kształtowania się cywilizacji w aspekcie psychologicznym, dzieło Eliasa przyciąga powabem barwnego, panoramicznego przekazu historii obyczajów (co uwzględnił polski tytuł skrótowej postaci tego dzieła jako Przemiany obyczajów w cywilizacji Zachodu). Otrzymujemy w nim nasycony realiami obraz życia codziennego średniowiecza i czasów nowożytnych, przekazany w sposób poglądowy, intuicyjnie uchwytny, tchnący autentycznością a przede wszystkim dbały o kształt literacki. Nie bez znaczenia jest tu oczywiście fakt, że szczegółowe dane dotyczące obyczajowości człowieka dawnych wieków czerpał Elias - sam doskonały pisarz - z dzieł o wysokim walorze literackim.

Jeśli proces ucywilizowania, który polega na kontroli afektów, składa się z szeregu zmian w życiu emocjonalnym jednostki, prowadzących do wykształcenia się jej coraz to większej samokontroli, to u podstaw tego procesu nie może stać homo clausus jako jednostka wyobcowana/

18 Por. N. Elias, O procesie cywilizacji..., s. 195. 
/wyosobniona/izolowana, a przede wszystkim wyposażona w jakiś niezmienny zasób cech. Tym, co w jednostkach podlega zmianie w rezultacie międzyosobowych oddziaływań i następnie jest dziedziczone społecznie - bowiem jednostka powtarza w swoim rozwoju cywilizacyjnym rozwój społeczeństwa ${ }^{19}$ - jest życie uczuciowe, stan afektów, które, podlegając samokontroli, formują stopniowo jednostkę coraz to bardziej opanowana, wewnątrzsterowna, wrażliwą na innych i bardziej wyczulona/wybredną w stosunku do samej siebie. Za wykształceniem się w jednostce uczuć wstydu/zakłopotania i przykrości stoi proces historyczno-społeczny, niezależnie od którego uczuć tych nie tylko nie można badać, ale nie można ich w ogóle zrozumieć. Te uczucia zdają się wprawdzie być naturalnymi i przyrodzonymi, jednak w rzeczywistości zostały $\mathrm{w}$ jednostce wykształcone przez naciski płynące z zewnątrz od innych ludzi. W dziedzinie życia emocjonalnego natura splotła się $\mathrm{z}$ historią. Doszło do zmiany w sposobie odczuwania jednostki, zmiany rozpowszechniającej się następnie i stabilizującej jako pewna "norma” i społeczny wzór. Stopniowe gromadzenie się tych zmian doprowadziło w procesie cywilizacji do powstania nowych form i norm społecznego zachowania, oddziaływujących z kolei zwrotnie na jednostkę. Abstrakcyjne pojęcia, za pomocą których wyrażona jest tu i przekazana myśl Eliasa, mają jednak swoje intuicyjne wypełnienie w ilustracjach konkretnych zachowań ludzi w sytuacjach życia codziennego. Jak symboliczną i przełomową rolę odgrywa w historii ludzkiej cywilizacji zwykły widelec czy osobne talerze dla biesiadników, niech wskaże następujący fragment z dzieła Eliasa:

Ludzie, którzy jedzą zgodnie z przyjętymi w średniowieczu regułami, biorą mięso rękami z tej samej miski, piją wino z jednej czarki, czerpią zupę z jednego garnka czy talerza - nie mówiąc już o innych osobliwościach ich zachowania [...] - ludzie ci mają do siebie inny stosunek niż ludzie naszych czasów. I to nie tylko w sferze świadomości, w sferze świadomych i sprecyzowanych motywacji, inna bowiem jest struktura i inny charakter ich życia emocjonalnego [...] To, czego brak w tym świecie [...] to ów niewidzialny mur napięć emocjonalnych, które w naszych czasach wznoszą się między ciałami ludzi, rozdzielając je i odpychając od siebie ${ }^{20}$.

Ten proces obrazowo opisany jako „rozdzielanie i odpychanie od siebie" ciał zostaje też uznany za symptom postępu cywilizacyjnego jako „potęgowanie się wewnętrznego nakazu samokontroli" ${ }^{21}$, na którym po-

19 „W każdym człowieku dokonuje się od nowa w skończonej formie proces historyczno-społeczny, który trwał stulecia i w toku którego wykształciły się powoli standard wstydu i przykrości", w: N. Elias, O procesie cywilizacji..., s. 196.

20 N. Elias, O procesie cywilizacji..., s. 139.

${ }^{21}$ Ibidem, s. 152. 
lega proces cywilizacji. „Widelec nie jest niczym innym, jak ucieleśnieniem określonego standardu emocjonalnego"22.

Na przykładzie sposobu jedzenia, zachowania się przy stole ilustruje Elias „zmianę struktur popędowych i emocjonalnych". Zaspokojenie naturalnej potrzeby głodu okazuje się występować w postaci wystylizowanej historycznie i związanej z pewną określoną strukturą życia emocjonalnego. To, co mogłoby wydawać się dane przez naturę, zostaje uformowane społecznie przez sytuacje, które naciskiem z zewnątrz ograniczają jednostkę w jej afektach. Uczucia wstydu i zakłopotania, obok strony naturalnej, mają stronę ukształtowaną społecznie. Czysty stan natury, przeciwstawiony cywilizacji, w świetle rozważań Eliasa nie istnieje. W tym sensie również psychikę ludów pierwotnych uznaje za ukształtowaną historycznie, chociaż bez udziału historycznej świadomości. „Nie ma punktu zerowego historyczności w ewolucji człowieka"23. „Człowiek bez restrykcji to złudzenie"24.

Elias barwnie i interesująco opowiada o przymusach nakładanych na psychikę ludzi przeszłości, restrykcjach, które wywarły wpływ na wykształcenie się struktury ich życia emocjonalnego, a w rezultacie dalekosiężnych oddziaływań, również naszego współczesnego. Jak już wyżej wspomniano, są to relacje zakorzenione w konkretnych badaniach historycznych i kulturoznawczych, w empirii, która służy do zbudowania pewnej teorii. I tak $\mathrm{z}$ historii feudalizmu wydobywa Elias proces zwany przez siebie "udwornieniem wojowników” jako milowy krok przemian cywilizacyjnych w kierunku człowieka nowożytnego. Proces ten odtworzył następnie G. Böhme w cytowanej wyżej Antropologii filozoficznej25, dlatego ograniczę się tu do przedstawienia aspektu pominiętego $\mathrm{w}$ tej relacji, a skupionego wokół częściowo rycerskiego pochodzenia działających na dworach wczesnośredniowiecznych trubadurów i minnesingerów.

Do procesu „udwornienia wojowników” dochodzi na dworach francuskich w wiekach XI-XII. Ich znaczenie cywilizacyjne jako ośrodków mecenatu dla literatury i dziejopisarstwa oraz centrów wykształcania się nowych form życia trudno dziś przecenić. Oto drobni rycerze, pozbawieni ziemi lub nie mogący się z niej wyżywić, szukają schronienia na dworach, gdzie stają się częścią orszaku możniejszego od siebie pana feudalnego. W rezultacie doprowadzają do pacyfikacji własną rządzę panowania, wyrażającą się w poprzednim ich stanie społecznym jako niczym nie skrepowany rozbój. O ile sprzyja temu ich talent i umiejętności, zostają pisarzami dworskimi, administratorami, dziejopisami opiewają-

\footnotetext{
22 Ibidem, s. 194.

23 Ibidem, s. 227.

24 Ibidem, s. 281.

25 Por. G. Böhme, Antropologia filozoficzna..., s. 225.
} 
cymi wojenne przewagi swojego pana lub wreszcie, co ma szczególne znaczenie cywilizacyjne, trubadurami i minnesingerami. Trzeba dodać, że ci ostatni rekrutowali się społecznie nie tylko ze zbiedniałej warstwy rycerskiej, poszukującej oparcia na dworach, ale również ze środowisk miejskich i skromnych wiejskich. W długotrwałym procesie ich adaptacji do dworu i panujących tam stosunków, drobny rycerz, początkowo „dziki, okrutny, skłonny do wybuchów i natychmiastowego zaspokajania swoich żądz" zostaje zmuszony do nałożenia sobie ograniczeń. Na ten przymus składa się i decyduje o nim z jednej strony podległość i służbowa zależność od możnej postaci pana lennego, z drugiej zaś rola wobec dostojnej małżonki seniora, która stopniowo w poezji trubadurów i minnesingerów staje się obiektem uwielbienia i czci, opiewanym w poezji miłosnej. Znalazłszy się na dworze, rycerz przekształcający się w dworzanina przytłumia swoje emocje, sublimuje je, przystosowując się stopniowo do nowej roli społecznej w zmienionej „figuracji”. Wcześniejsze, brutalne formy jego życia, pochodzące z czasów, gdy środki utrzymania zdobywał sobie rozbojem, zostają zastąpione formami bardziej wyszukanymi, dworskimi, czyli właśnie „kurtuazyjnymi”. „Poeci, zarówno szlacheckiego, jak też mieszczańskiego pochodzenia, są ludźmi zależnymi społecznie i ten stosunek zależności służbowej stanowi podstawę ich śpiewu, podstawę kształtowania się ich popędów i emocji"26. Dwór, zogniskowany wokół pani dworu - a jego wspaniałość odpowiada militarnej potędze i posiadaniu ziemi przez jej rycerskiego małżonka - wytwarza "utemperowane” formy współżycia, wykształca nowe postaci wrażliwości. Uwidoczniają się one poza poezją już w samej pracy administracyjnej, która domaga się sprawności nie miecza, lecz pióra i wytwarza atmosferę bardziej pokojową. Do wydelikacenia, wysubtelnienia obyczajów dochodzi przede wszystkim w liryce miłosnej trubadurów, społecznie opartej na stosunku między wyżej stojącą panią dworu a niżej usytuowanym jej admiratorem i piewcą. Tam, gdzie mężczyzna przez sytuację zostaje zmuszony do rezygnacji z siły fizycznej, rośnie znaczenie kobiety. Szczególne znaczenie cywilizacyjne w procesie „udwornienia wojowników” przypisuje Elias właśnie stosunkowi niżej stojącego mężczyzny do górującej nad nim społecznie kobiety; między strukturą tego stosunku a postacią życia emocjonalnego zachodzi jego zdaniem ścisły związek ${ }^{27}$. Tak więc określona sytuacja społeczna, określony układ stosunków międzyludzkich stanowi tło wykształcania się liryki, a wraz z nią pewnego wysublimowanego wzoru erotyki, formy miłości w twórczości trubadurów i minnesingerów. Ten nowy wzór życia emocjonalnego, następnie przenoszony społecznie i przejmowany przez szersze warstwy, oparty na większym okiełznaniu, utemperowa-

26 N. Elias, O procesie cywilizacji..., s. 360.

27 Ibidem, s. 364. 
niu i ustabilizowaniu zachowań i relacji emocjonalnych, różni się zdecydowanie od nieopanowanej, pożądliwej emocjonalności rycerskiej. Tak oto Elias dochodzi jeszcze raz do wniosku, że wraz ze zmianami sieci zależności między ludźmi, ich popędy zmieniają swoją postać w strukturze życia psychicznego, zmienia się forma wrażliwości, postać życia emocjonalnego. To właśnie te zjawiska decydują o historyczności ludzkiego istnienia. Wraz ze zmianami społecznymi ulega przemianie model całego życia emocjonalnego, struktura psychiki. Dzieje się tak w długim procesie ewolucyjnym, w którym historia wykształca osobowość. Na podstawie wyróżnionego tu aspektu „udwornienia wojowników” staje się widoczne, jak historia modeluje naturalne predyspozycje człowieka i wytwarza stopniowo wzory zachowań bardziej „cywilizowanych".

Decydująca, zdaniem Eliasa, rolę w narzucaniu ludziom powściągliwości i umiaru spełniała w procesie cywilizacyjnym władza centralna. Wspominaliśmy już wcześniej, że proces cywilizacyjny odbywał się w ścisłym związku z kształtowaniem się państwa i rozwojem absolutyzmu. Ze względu na historyczną specyfikę tego wątku, domagającego się szczególnych kompetencji w zakresie wiedzy humanistycznej, nie możemy go tu rozwijać i ograniczymy się do wskazania jedynie w największym skrócie, na czym on polegał w aspekcie konsekwencji psychologiczno-osobowościowych. Otóż gdy ludzie na pewnym obszarze zostają zmuszeni do życia w sposób pokojowy (np. w procesie kształtowania się w feudalizmie władzy seniora nad wasalami), wówczas stopniowo zmienia się ich struktura emocjonalna i sposób funkcjonowania popędów. Jak pisze Elias:

rośnie z wolna względna powściagliwość i samoopanowanie, ludzie bardziej się ze sobą wzajem liczą. I wyładowanie afektów w agresji fizycznej ograniczone zostaje do określonych enklaw w czasie i przestrzeni. Z chwila, gdy monopol przemocy fizycznej przeszedł do władz centralnych, nie każdy, kto ma siłę, może dać upust popędowi agresji, dopuszczając się napaści fizycznej; mogą to czynić tylko nieliczni, uprawnieni do tego przez władzę centralną ${ }^{28}$.

Proces cywilizacji, odbywający się na drodze umocnienia władzy centralnej, powoduje zmianę zachowań, ewolucję odczuć, „strukturalną transformacje psychiki"29. Zmiany zachodzące w jednostkach przenoszone są następnie na wzory zachowań społecznych. Należy je „postrzegać nie z perspektywy ogólnoludzkich uwarunkowań o charakterze

28 Ibidem, s. 269.

29 Ibidem, s. 557. 
ahistorycznym, lecz jako coś ukształtowanego w trakcie procesu historycznego" ${ }^{\prime 3}$.

W tekście niniejszej noty wydobyliśmy z dzieła Norberta Eliasa te wątki, które wykazują doniosłość dla rozważań antropologii filozoficznej. Pominęliśmy skądinąd fundamentalne, bliższe określenie procesu cywilizacji oraz rozważania Eliasa o kształtowaniu się państw. O cywilizacji mówiliśmy w sensie „strukturalnej transformacji psychiki”. Staraliśmy się ukazać postulowaną przez niego plastyczność aparatury psychicznej, która stoi u podstaw modelowania popędów i wytwarzania zmieniających się w dziejach wzorów życia emocjonalnego. Ewoluujące formy ludzkiego życia nie oznaczają jeszcze dla Autora - jak sam zastrzega - jakkolwiek lapidarnie tylko w jednym sformułowaniu - zmienności natury ludzkiej; one nawet odsłaniają ", niezmienną specyfikę bytu ludzkiego".

Niemniej jednak myśli Eliasa dają nam na przyszłość odwagę do podjęcia chociażby próby krytycznego spojrzenia na teorie poszukujące przedwcześnie jednoznacznego ustalenia ludzkiej natury, wyznaczające sztywne "stałe antropologiczne", bez rezerwowania miejsca na historyczny aspekt ludzkiego istnienia. Dzieło Eliasa uwrażliwia nas na historyczność człowieka. Zmienność istoty ludzkiej sięga wystarczająco głęboko, aż po modelowanie jej popędów i w konsekwencji kulturowe stylizowanie całości życia emocjonalnego, aby za Eliasem mówić o historyczności człowieka ujawniającej się w procesie cywilizacji. Aby zrozumieć człowieka - postuluje Elias - trzeba wziąć pod uwagę nie tylko ratio, nie tylko świadomość, lecz należy uwzględnić jego popędy, emocje i namiętności, całość struktury jego psychiki, którą możemy tu określić jako wehikuł historyczności. Postulat ten należy odnieść do badań podejmowanych również przez antropologię filozoficzną. Dodajmy na zakończenie, że doniosłość $\mathrm{w}$ badaniach Eliasa ma także proces racjonalizacji, w trakcie którego kształtuje się ratio. Jako temat związany z bliższym określeniem procesu cywilizacyjnego pozostawiamy jednak myśli z nim związane do dalszego opracowania, uwzględniającego wątki historiozoficzne wielkiego studium Eliasa.

Z rozpoznań Norberta Eliasa może skorzystać antropologia filozoficzna zarówno w aspekcie krytycznym, jak też interdyscyplinarno-poszerzającym: poddając refleksji, ewentualnie podważając jednostronność koncepcji poszukujących stałej i niezmiennej natury ludzkiej, zwłaszcza ograniczonej do rozumu, a także zmierzając w kierunku wykształcenia antropologii historycznej, właśnie na drodze czerpania z inspiracji, jakich dostarcza dzieło Eliasa.

30 Ibidem, s. 583. 


\section{Bibliografia}

Böhme G., Antropologia filozoficzna, przeł. P. Domański, przedmową opatrzył i redakcji naukowej dokonał Stanisław Czerniak, Wydawnictwo IFiS PAN, Warszawa 1998.

Bucholc M., Samotność dtugodystansowca. Na obrzeżach socjologii Norberta Eliasa, Wydawnictwo Naukowe PWN, Warszawa 2013.

Dilthey W., Typy światopogladów $i$ ich rozwinięcie w systemach metafizycznych, w: W. Dilthey, O istocie filozofii i inne pisma, przeł. E. Paczkowska-Łagowska, PWN, Warszawa 1987.

Dilthey W., Einleitung in die Geisteswissenschaften. Versuch einer Grundlegung für das Studium der Gesellschaft und der Geschichte, in: idem, Gesammelte Schriften, I. Band, B.G. Teubner Verlagsgesellschaft Stuttgart, Vandenhoeck \& Ruprecht in Göttingen 1992.

Elias N., O procesie cywilizacji. Analizy socjo- i psychogenetyczne, przeł. T. Zabłudowski i K. Markiewicz, Wydawnictwo WAB, Warszawa 2011.

Paczkowska-Łagowska E., O historyczności człowieka. Studia filozoficzne, słowo/obraz terytoria, Gdańsk 2012.

Suwada K., Miłość erotyczna w procesie cywilizacji. Próba interpretacji koncepcji Norberta Eliasa, Nomos, Kraków 2013.

\section{Streszczenie}

\section{Struktura osobowości a proces cywilizacji. Nota na temat historyczności człowieka w rozważaniach Norberta Eliasa}

Artykuł wydobywa z dzieła Eliasa O procesie cywilizacji. Analizy socjo- $i$ psychogenetyczne myśli na temat historyczności człowieka i ukazuje ich znaczenie dla kształtującej się antropologii historycznej, uwzględniającej rezultaty interdyscyplinarnych badań humanistycznych: filozofii, socjologii, psychologii. Abstrakcyjnemu podmiotowi poznania jako konstrukcji pojęciowej (homo clausus) Elias przeciwstawia człowieka całościowego jako osobowość, na którą składa się nie tylko ratio/intelekt, lecz również popędy, emocje, namiętności. Podlegają one modelowaniu w stosunkach międzyludzkich (figuracjach), odpowiadających zmiennym historycznie formom życia. Psychospołeczne badania Eliasa nad historycznością człowieka poprzedził filozof Wilhelm Dilthey. Badając proces rozwoju cywilizacji polegający na rosnącej kontroli afektów, Elias wypełnia Diltheya koncepcję człowieka historycznego bogactwem treści pochodzących z dziejów obyczajowości oraz procesów kształtowania się państwa i rozwoju absolutyzmu. Na barwnych przykładach zmienności form zachowania się przy stole, stosunku do drugiej płci pokazuje, jak sposób funkcjonowania ludzkich popędów zmienia się w procesie cywilizacji. Historyczność człowieka oznacza 
zmienność form ludzkiego życia, a wraz z nimi zmienność struktury życia emocjonalnego/świadomości/osobowości.

Słowa kluczowe: Homo clausus, człowiek całościowy, figuracje, proces rozwoju cywilizacji, człowiek historyczny W. Diltheya, interpretacje świata ze stanowiska różnych stron ludzkiej natury: intelektu, woli, uczucia, modelowanie popędów i uczuć, transformacja psychiki/osobowości w dziejach, historyczność człowieka

\section{Summary}

\section{The structure of a personality and the process of civilizing. The note on the historicity of man in Norbert Elias's deliberations}

From Elias`s The Civilizing Process. Sociogenetic and Psychogenetic Investigations the article extracts ideas on human historicity and shows its significance for the constitution of historical anthropology which considers the results of interdisciplinary humanistic research: philosophy, sociology, psychology. Elias places the nonfigurative subject of experience as a conceptual structure in opposition to the "total man" as a personality which includes not only ratio/ intellect/mind but also urges, emotions, passions. These are subject to shaping in interpersonal relations corresponding to historically variable forms of life. Elias`s psycho-sociological research over human historicity was preceded by Wilhelm Dilthey. Having studied the evolution of civilization consisting in a growing emotion/ affect control, Elias fills Dilthey's conception of historical man with rich content derived from the history of customs and state forming processes as well as the development of absolutism. He uses vivid examples of the manners in which dining etiquette and approach to the opposite sex evolved to show how human functioning urges changes during the process of civilization. Human historicity means changing forms of human life and changing the structure of emotional life along with.

Keywords: Dilthey, Elias, homo clausus, total man, figurations, civilizing process, historical man, world 's interpretation from different point of view: intellect, will, passions, modeling of impulses and passions, transformation of psyche/ personality in history, historicity of man 